\title{
FESTIVAL
}

\section{DE CANNES 95}

\section{Campanhas publicitárias, mesmo com produções milionárias, não dis- pensam a criatividade}

Todo ano no início do verão acontece o que se poderia chamar de a grande mostra da criação publicitária mundial: o Festival Internacional do Filme Publicitário que, de quatro anos para cá, também tem se dedicado à mídia impressa.Os plublicitários, como sempre, por se acharem superbacanas, não poderiam deixar de realizá-lo no mesmo local onde acontece o badaladíssimo festival de cinema, o balneário de Cannes, na Riviera francesa. Uma cidade que se assemelha ao nosso Guarujá, mas onde se vêem senhores que andam com aqueles quepes de comandante, paletó azul marinho com um daqueles brasões dourados no peito, calça e sapatos brancos e lenço no pescoço, e praias que cobram uma média de 100 francos (cerca de 20 dólares) de entrada para aquelas pessoas que não estão hospedadas nos hotéis cinco estrelas que as circundam e não querem se espremer nos dois pequenos espaços públicos que estão localizados nas pontas da praia.

\section{MARATONA}

O festival publicitário era feito em Veneza no início - por isso os famosos leões, símbolo dessa cidade, como prêmio - e se mudou para Cannes acho que pela total infra-estrutura montada para os eventos que acontecem sem parar.
O festival é uma verdadeira maratona de propaganda. Cinco dias com uma média de nove horas de exibição diária de filmes publicitários.

Nos primeiros três dias mostra-se a totalidade das centenas de filmes inscritos que são divididos de acordo com as categorias dos produtos e serviços que anunciam.

No quarto dia mostra-se o short list, que é o resultado da seleção feita pelo júri dos filmes que irão concorrer aos leões de ouro, prata e bronze.

E no último dia o resultado final e a festa de premiação. Enfim, um verdadeiro porre.

Apesar de conhecer de muito o famoso rolo dos filmes premiados, foi a primeira vez que acompanhei ao vivo o festival.

A primeira impressão é a de que, apesar de nas fitas com os ganhadores - comercializadas após o encerramento - se encontrarem a nata dos comerciais apresentados, muita coisa boa fica de fora e, conseqüentemente, fora dos anais da propaganda mundial.

\section{O AUTOR}

José R. D'Elboux

Publicitário, atualmente trabalha no Departamento de Criação da agência Young \& Rubicam, em São Paulo. 
O mais interessante é que os primeiros dias de festival são bastante tranqüilos em termos de audiência, e no dia da exibição do short-list é muito difícil se conseguir um lugar nos auditórios, tomados pelos publicitários europeus, que deixam para acompanhar o festival a partir daí, e também por muitos brasileiros que preferiam a piscina ou a praia dos hotéis aos escuros e gelados auditórios do Palais des Festivals.

Com certeza perderam o melhor da propaganda da Croácia e da Rússia. Não é para rir não, mas nossos colegas da antiga cortina de ferro, apesar de estarem engatinhando em termos de criação de propaganda, produzem com a qualidade das melhores produtoras de cinema da Europa, deixando muitos dos filmes brasileiros comendo poeira em termos de produção.

Esse é um assunto à parte, pois dá para saber que o comercial é brasileiro, já pela péssima qualidade da imagem que se projeta na tela, sem nem precisar entrar em detalhes mais complicados como fotografia e produção.

Por isso quando um filme brasileiro ganha um prêmio no festival, é que ele é muito bom mesmo (em termos de idéia, é claro).

\section{SIMPLES E UNIVERSAL}

Há comerciais europeus e norte-americanos nos quais não se encontra nem cheiro de uma boa idéia publicitária, mas o padrão de produção e efeitos chega a um nível tão absurdamente espetacular que deleitam a platéia.

Outro ponto interessante refere-se às características regionais de onde foram feitos, coisa que está se tornando cada dia mais rara, não por não existirem e sim por não serem inscritos, pois para uma platéia e para um júri internacional existem coisas da cultura regional de cada país que seriam verdadeiros enigmas.

Lembro, certa vez, de um jurado brasileiro comentar que seus colegas europeus estavam surpresos ao verem que a estética e as personagens presentes em nossos filmes eram exatamente o que se encontrava nos filmes americanos e europeus. Algo inconcebível para eles que esperavam ver em nossos filmes uma caracterização completamente diferente, mais própria e regional.

A única exceção a essa regra é a propaganda japonesa. Ela é tão estranhíssima e maluca aos nossos olhos de pobres ocidentais, que acaba se transformando em um verdadeiro cult do festival.

Tudo isso é meio óbvio, pois a propaganda na verdade só reflete $o$ anseio dos consumidores que querem se ver retratados como cidadãos do primeiro mundo e não como a massa mulata que realmente são.

O outro motivo é que cada dia mais as grandes empresas optam por uma comunicação internacional, algo que fale com as pessoas em todas as partes do mundo da mesma maneira, como a Coca-Cola que espalhou seus ursos polares ao redor do mundo.

Ela vai se tornando cada dia mais visual e menos textual.

Você vai assistindo a todos aqueles comerciais e se pergunta como selecionaria dois ou três para serem premiados.

Eu acho que desenvolvi um método infalível. Depois de assistir a três horas e meia de comerciais de carros, você puxa pela memória e descobre que não consegue se lembrar de mais do que cinco filmes. Pronto. Estão aí os melhores da categoria. E geralmente são idéias simples com execução correta, sem precisar de um festival de 
efeitos especiais, que só impressionam enquanto estão acontecendo.

\section{BOA IDÉIA}

Como um comercial da Volvo, na minha opinião o melhor da categoria de carros. Esse anunciante tem por tradição fabricar os veículos seguindo normas estritas de segurança, e a propaganda sempre se baseia nesse fato.

Para isso foi feito um filme, na verdade uma coletânea de cenas de estradas e ruas, imagens precárias e em preto e branco, feitas por aquelas câmeras automáticas que a polícia utiliza para posteriormente multar os infratores que aparecem nos filmes. São cenas de motoristas cometendo verdadeiras barbaridades nas ruas e auto-estradas européias, e no final, junto com o logotipo do fabricante, aparece a frase: "Compre um Volvo. Afinal, você nunca sabe quem está do outro lado da curva".
Tão genial que não precisou nem ser filmado, as imagens já estavam prontas para usar nos arquivos da polícia.

Ou como a famosa campanha para a Pepsi-Cola, todo ano um sucesso no festival. Este ano, entre outras obras-primas, havia um filme no qual se via um daqueles restaurantes de estrada dos Estados Unidos. Estacionados do lado de fora um caminhão de Coca e, claro, outro de Pepsi. Corta para o interior do restaurante onde os motoristas estão sentados no balcão. O motorista da Coca oferece seu refrigerante para o outro, que recusa mostrando que já está tomando sua Pepsi. O outro insiste novamente e eles acabam trocando de bebidas, só que quando o motorista da Pepsi devolve a garrafa de Coca o outro se recusa a devolver a de Pepsi, e acaba no maior quebra-pau.

Os filmes japoneses não me atrevo a contar, só mesmo vendo. 